ISSN 1112-9867

\title{
IN TRAIN AIR QUALITY ANALYSIS OF THE PUBLIC RAILWAY TRANSIT AND PUBLIC PERCEPTION ON IN-TRAIN AIR QUALITY IN MALAYSIA
}

\author{
M. Masyita* and R. Nornadiah \\ Environmental Health Section, Universiti Kuala Lumpur-Institute of Medical Science \\ Technology, Kajang, Selangor, Malaysia
}

Published online: 05 October 2017

\begin{abstract}
This study analyze the trend of in-train air quality in KTM Commuter in upstream and downstream lines, identify public's perception and knowledge on in-train air quality. Real time monitoring was conducted by measuring five indoor air parameters (CO2, CO, PM10, temperature and humidity) along Klang Valley Line from SgBuloh until PelabuhanKlang station for five consecutive days, together with a survey on IAQ facts and symptoms related to indoor air pollutants among 129 KTM commuter passengers. Descriptive and correlation tests were performed using SPSS version 23. $\mathrm{CO}_{2}$ and PM10 concentration in most of the time have exceeded permissible limit $\left(\max =1449 \mathrm{ppm}\right.$ and $\left.>0.15 \mathrm{mg} / \mathrm{m}^{3}\right)$. CO concentration was below permissible limit $(<10 \mathrm{ppm})$, whilsttemperature and humidity were mostly in an acceptable range $\left(23-26^{\circ} \mathrm{C} ; 40-70 \% \mathrm{rh}\right)$.
\end{abstract}

Keywords: In-train air quality (IAQ); KTM commuter carbon dioxide; carbon monoxide; particulate matter (PM); public perception.

Author Correspondence, e-mail: masyita@unikl.edu.my

doi: http://dx.doi.org/10.4314/jfas.v9i4s.46 


\section{INTRODUCTION}

The urban transport system is evolving which eventually lead to traffic congestion. Due to this problem, people relies more on the usage of public transport to avoid traffic congestion when commuting to work [1]. In addition, these people had spent about 90 minutes commuting every day to work of which indirectly forced them to spent time in indoor environment [2].

Although the interest in indoor air quality (IAQ) studies has been arising, very little studies were focused on IAQ of subway and railway vehicle cabins [3-4]. It was postulated that prolonged exposure during commuting may produce significant health effects and well-being of occupants. Few symptoms related to in train air quality include headache, drowsiness, irritation to eyes and nose [3,5]. Despite of the adverse health effect of prolonged exposure reported, comfort issue is another major concern of public transport commuter which include overcrowding and inconvenience of the current units and locomotives [6].

Kuala Lumpur city with population estimated of 1.76 million has seen a rapid growth in public railway transit system. KTM commuter is one of the intercity railway transit systems that served approximately 900,000 passengers in Kuala Lumpur and its surrounding suburban areas [7]. It comprised three lines: Rawang-Seremban; Sentul-Port Klang and Rawang-Kuala Kubu Baharu [8]. The railway transit system is expected to play an even greater in the coming years. Thus, this present study aim to assess the in train air quality and public knowledge and perception on IAQ of the system.

\section{METHODOLOGY}

In train air quality was assessed along Port Klang line (Sungai Buloh-Port Klang) for five consecutive days (both upstream and downstream lines). The route was chosen due to its location at the centre of industrial area. Air samples were taken during off-peak hour due to KTM Berhad company permission (10.00 am-12.00 pm and 12.30 pm-2.30 respectively). The IAQ monitoring involved physical parameters (air temperature and relative humidity) and chemical parameters $\left(\mathrm{CO}, \mathrm{CO}_{2}\right.$ and $\left.\mathrm{PM}_{10}\right)$. Samples were collected based on Malaysia Code of Practice Indoor Air Quality [9] where the IAQ monitor and TSI dust track portable 
monitor were installed between two train compartments (Fig. 1). Relevant information such as ventilation from air conditioning, weather, train speed and number of passengers were taken into consideration as such may affect in-train air quality. All air parameters (physical and chemical parameters) were compared against the permissible limit as endorsed by [10] (Table 1 and Table 2).

A survey was conducted in order to assess public awareness and perceptions on indoor air quality (IAQ). 384 respondents were to be recruited based on sample size calculated [11]. However, only 33\% of respondents were successful recruited (129 respondents) using convenience and snowball sampling. Respondents were urban rail transit commuters who used KTM commuter and aged between 17 to 65 years old.

Respondents were briefed on the study and consented before questionnaire administration. A set of bi language questionnaire (BahasaMelayu, English) was administered using an online survey or self-administered. The questionnaire consisted of demographic, indoor air quality facts, in-train condition and past/present symptoms or disease related to indoor air pollutants (adapted and modified from [11-12]).

Data was analysed using SPSS version 23 that consists descriptive analyses (frequency, means and percentage) and correlation analyses within the parameters stated. A value of $\mathrm{p}<0.05$ was set as statistical significant.

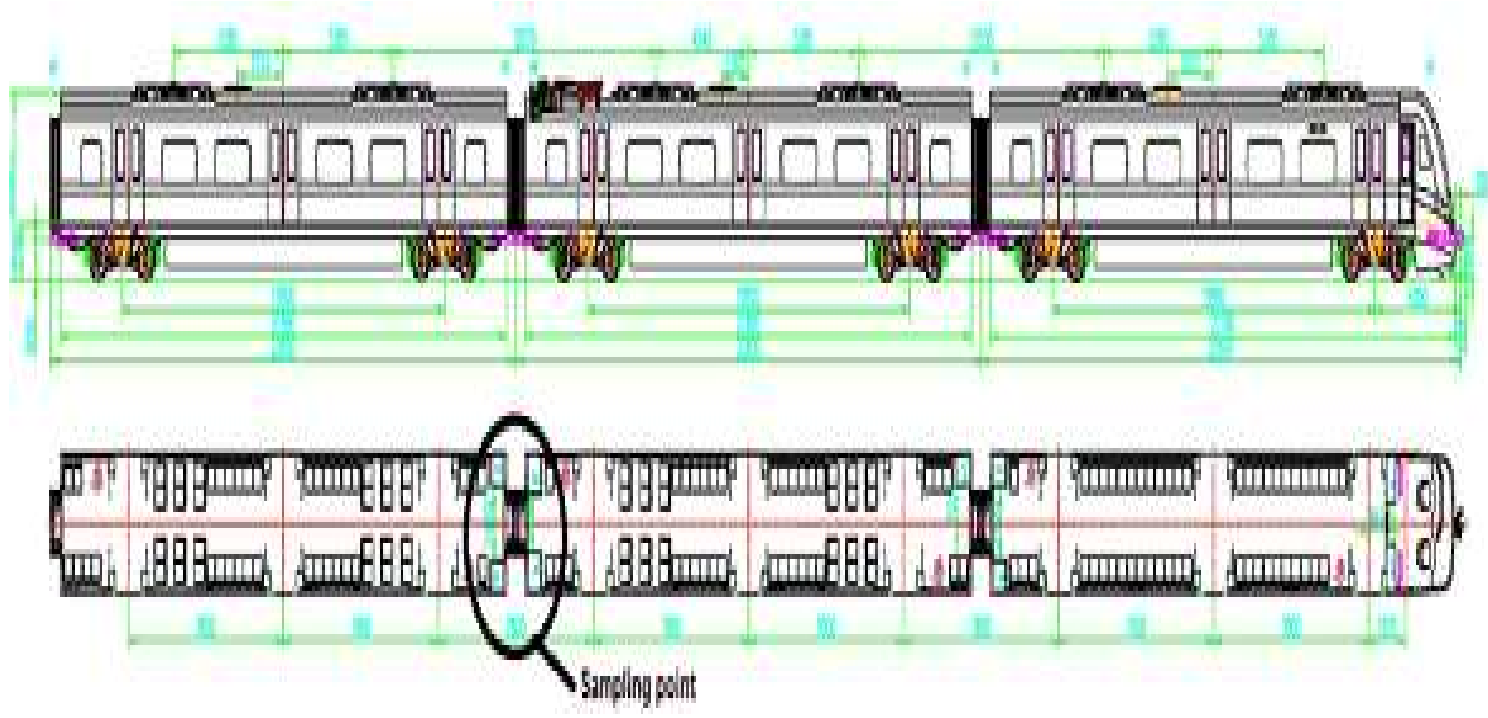

Fig.1. Sampling point overview based on train layout (KTM Berhad) 
Table 1. List of indoor air contaminants and the acceptable limits [9]

\begin{tabular}{lccc}
\hline \multicolumn{1}{c}{ Indoor Air Contaminants } & \multicolumn{2}{c}{ Acceptable Limit } \\
& $\mathrm{ppm}$ & $\mathrm{mg} / \mathrm{m}^{3}$ & $\mathrm{Cfu} / \mathrm{m}^{3}$ \\
\hline Chemical contaminants & 10 & - & - \\
a. Carbon Monoxide & 0.1 & - & - \\
b. Formaldehyde & 0.05 & - & - \\
c. Ozone & - & 0.15 & - \\
d. Respirable Particulates & 3 & - & - \\
e. Total Volatile Organic compounds (TVOC) & & & \\
Biological contaminants & - & - & $500^{*}$ \\
a. Total bacterial counts & - & - & $1000^{*}$ \\
b. Total fungal counts & & & \\
Ventilation performance indicator & C1000 & - & - \\
a. Carbon dioxide &
\end{tabular}

Excess of bacterial count does not necessarily imply health risk but serve as an indicator for further investigation*

Table 2. Acceptable range for specific physical parameters [9]

\begin{tabular}{rlc}
\hline & Parameter & Acceptable Range \\
\hline a. & Air temperature & $23-26^{\circ} \mathrm{C}$ \\
b. & Relative humidity & $40-70 \%$ \\
c. & Air movement & $0.15-0.50 \mathrm{~m} / \mathrm{s}$ \\
\hline
\end{tabular}

\section{RESULTS AND DISCUSSION}

\subsection{Chemical contaminants}

Carbon dioxide $\left(\mathrm{CO}_{2}\right)$ concentration reading was varied along the five days record (figure mean $\mathrm{CO}_{2}$ reading were $1007 \pm 53.25 \mathrm{ppm}$ and $1217 \pm 112.84 \mathrm{ppm}$ for downstream and upstream respectively). The $\mathrm{CO}_{2}$ concentration exceeds permissible limits $(>1000 \mathrm{pm})$. The high concentration might be due to the increase of number of passenger on board which increase the $\mathrm{CO}_{2}$ exhalation $[3,13]$. This slight increase only occur when the passenger boarding at KL Sentral station (Table 1). Pearson correlation revealed strong positive 
correlation between number of passengers and $\mathrm{CO}_{2}$ concentration on day- 3 upstream $(\mathrm{r}=0.82$, $\mathrm{p}=0.000$ ) and moderate positive correlation on day-5 upstream. Nevertheless, a strong negative correlation was observed on day-1 upstream between number of passengers and $\mathrm{CO}_{2}$ concentration despite of the maximum 69 passengers $(r=-0.735, p=0.000)$. The possible explanation to this correlation may be due to the high speed of the train that contributes to the increase of $\mathrm{CO}_{2}$ concentration [3]. Table 2 summarizes the correlation coefficient for both upstream and downstream line.

Carbon monoxide (CO) concentration on the other hand recorded low reading within the range of 0.0 to $0.3 \mathrm{ppm}$ during five days sampling. The reading was below acceptable limit of 10 ppm (Fig. 2). A high reading was recorded on day 5 for both downstream and upstream line (1.9ppm and $1.0 \mathrm{ppm}$ respectively). This can be explained due to outdoor environment influence, occur when the train door opened [1].

Furthermore, particulate matter (PM 10) concentrations recorded reading above acceptable limit $\left(>0.15 \mathrm{mg} / \mathrm{m}^{3}\right)$ throughout the five day sampling (Fig. 3). Mean $\mathrm{PM}_{10}$ concentration for downstream line was $0.9618 \pm 0.03 \mathrm{mg} / \mathrm{m}^{3}$, whilst the upstream line was $0.9965 \pm 0.02 \mathrm{mg} / \mathrm{m}^{3}$. This increase might be due to several factors. Based on the observation, dusts transferred from outdoor environment when the train door opened and a small gap (for train expansion during hot weather) between the compartments are the possible factors that allow dusts to enter into the train. Another factor that may contribute to the increase of $\mathrm{PM}_{10}$ reading are the frequency of ventilation and air conditioning maintenance and the commuter re-suspension movement $[3,14]$.

\subsection{Physical parameters}

The relative humidity measures were within the acceptable range (40\%-70\%) with mean $61.48 \%$ and $54.21 \%$ for downstream and upstream lines respectively (Fig. 5).Increase during data recording can be due to the increase number of passengers [3].

Similarly, the in-train temperatures recorded were within the acceptable range $\left(23^{\circ} \mathrm{C}-26^{\circ} \mathrm{C}\right)$ (Fig 4). Mean temperature was $22.78 \pm 0.58^{\circ} \mathrm{C}$ and $23.5 \pm 0.66^{\circ} \mathrm{C}$ for downstream and upstream lines respectively. There were some increase on the in-train temperature recorded and this was noted from the shutting down of air conditioning in the cabin for a while. 


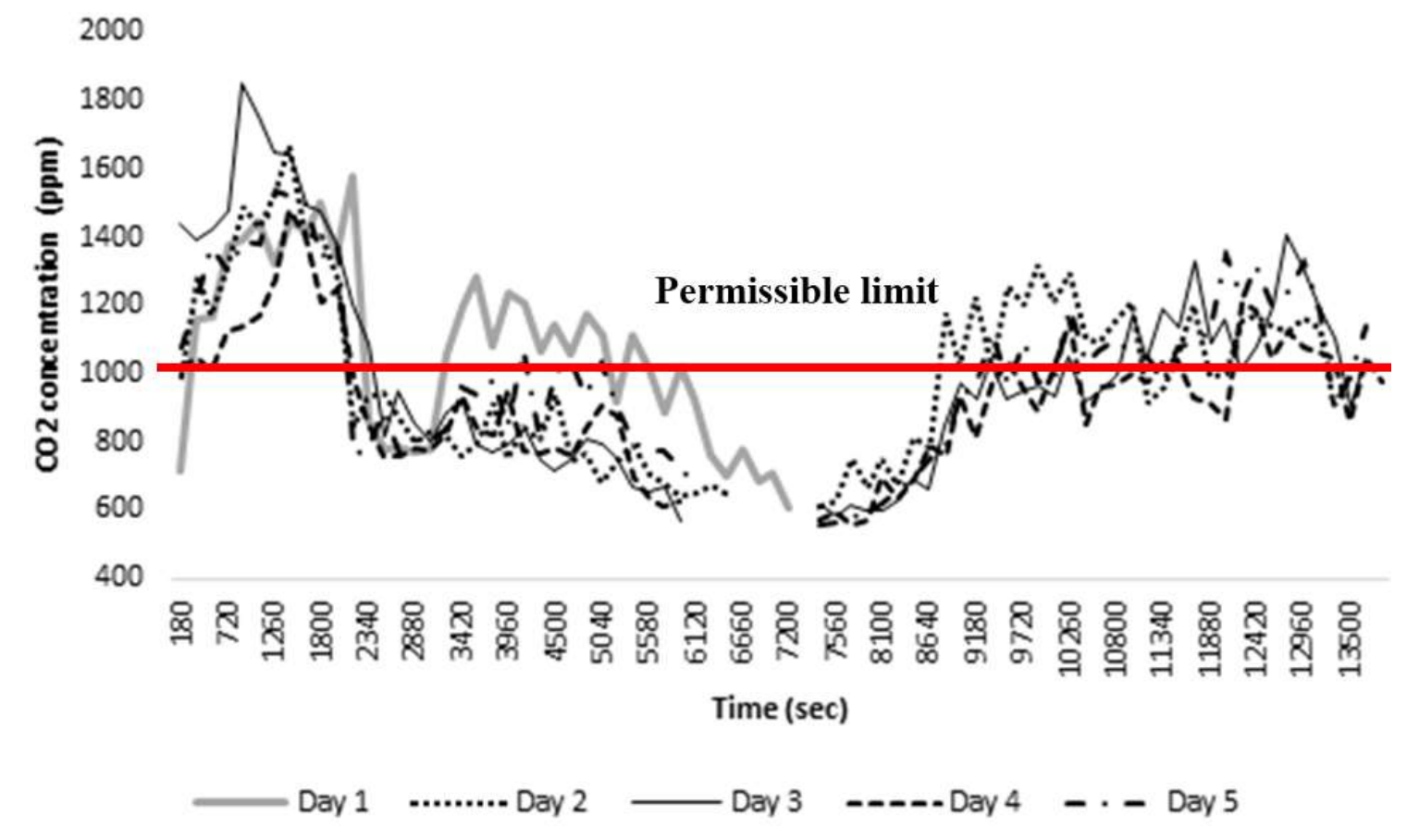

Fig.1.Trend of $\mathrm{CO}_{2}$ concentration for downstream and upstream lines

Table 1.Number of passengers on board for downstream and upstream line

\begin{tabular}{ccc}
\hline Line/Days & \multicolumn{2}{l}{ Average Number of Passengers } \\
& Min & Max \\
\hline & \multicolumn{2}{c}{ Downstream } \\
2 & 8 & 69 \\
3 & 7 & 78 \\
4 & 12 & 97 \\
5 & 8 & 77 \\
& & 84 \\
1 & - & - \\
2 & 10 & 82 \\
3 & 2 & 119 \\
4 & 5 & 114 \\
5 & 5 & \\
\hline
\end{tabular}


Table 2. Correlation between $\mathrm{CO}_{2}$ concentration and number of paasangers fordownstream and upstream line

\begin{tabular}{|c|c|c|c|}
\hline \multirow{2}{*}{$\begin{array}{c}\text { Downstream } \\
\mathrm{CO}_{2} \text { Concentration }\end{array}$} & \multicolumn{3}{|c|}{ Number of Passengers } \\
\hline & Day & $\mathbf{r}$ & P-Value \\
\hline & Day 1 & -0.735 & $<0.001 * *$ \\
\hline & Day 2 & -0.348 & 0.081 \\
\hline & Day 3 & -0.181 & 0.376 \\
\hline & Day 4 & -0.345 & 0.084 \\
\hline & Day 5 & -0.201 & 0.326 \\
\hline Upstream & \multicolumn{3}{|c|}{ Number of Passengers } \\
\hline $\mathrm{CO}_{2}$ Concentration & Day & $\mathbf{r}$ & P-Value \\
\hline & Day 1 & - & - \\
\hline & Day 2 & 0.334 & 0.096 \\
\hline & Day 3 & 0.820 & $0.000 * *$ \\
\hline & Day 4 & 0.116 & 0.573 \\
\hline & Day 5 & 0.553 & 0.003 \\
\hline
\end{tabular}

Pearson correlation test was done to determine association between $\mathrm{CO}_{2}$ and number of passengers

**denotes statistically significant at $\mathrm{p}<0.05$

- reading are unable to obtained due to unexpected device problem

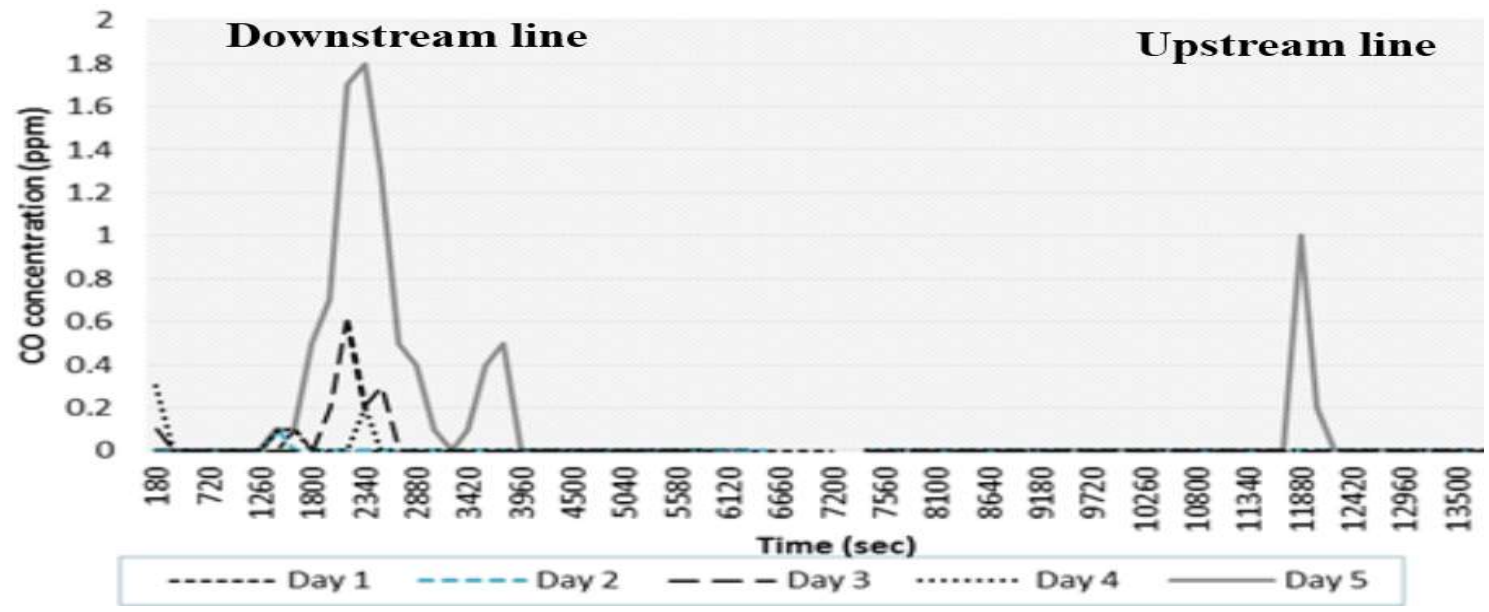

Fig.2. Trend of CO concentration for both downstream and upstream 


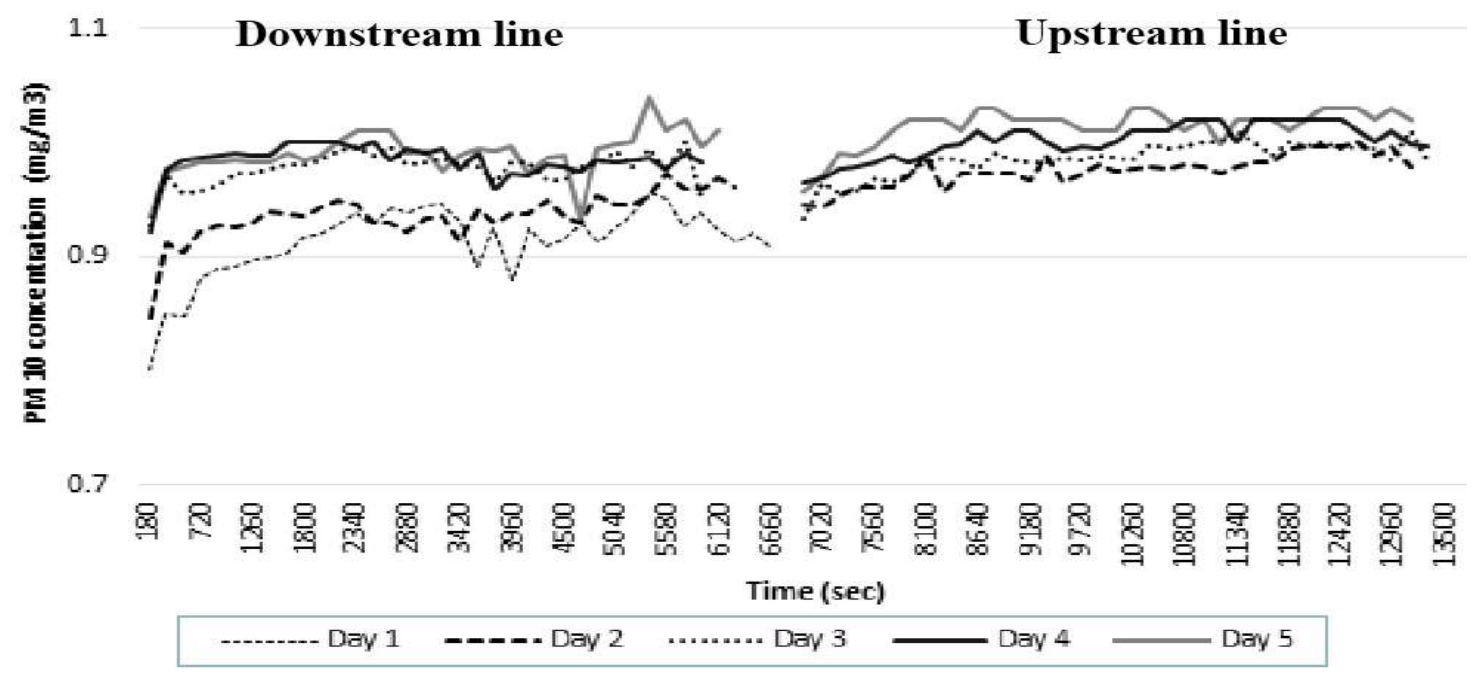

Fig.3.Trend of $\mathrm{PM}_{10}$ concentration for downstream and upstream lines
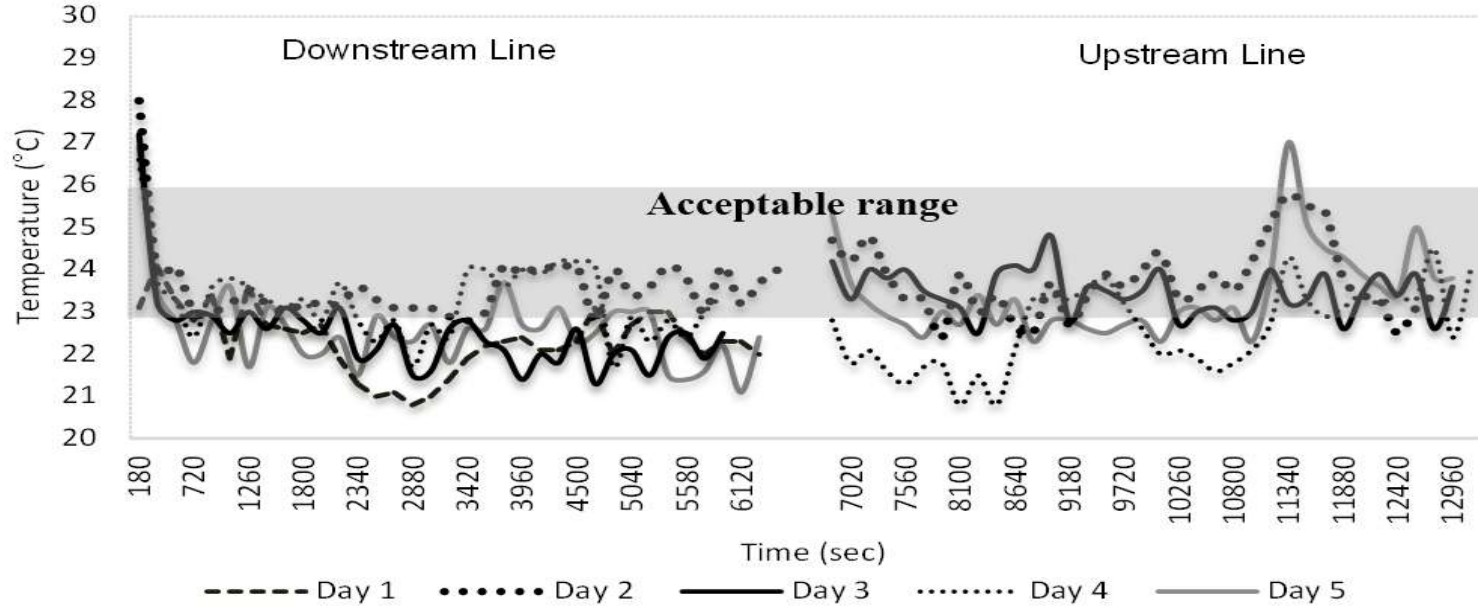

Fig.4. Trend of temperature in both upstream and downstream lines

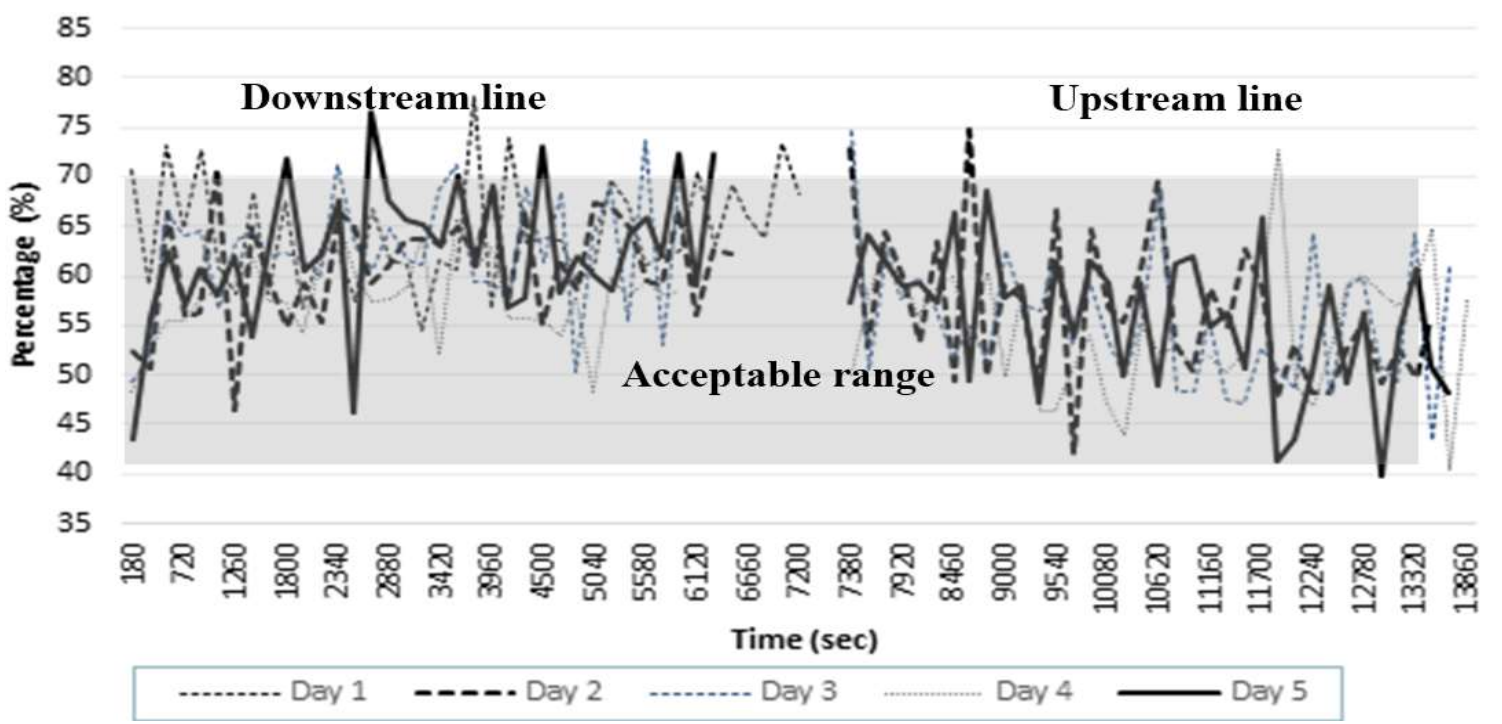

Fig.5. Trend of relative humidity for both downstream and upstream lines 


\subsection{Public Knowledge and Perception on Indoor Air Quality}

A total of 129 respondents participated in this survey. Most of the respondents were females and in the age of twenties. In addition, most of the commuters came from tertiary education background. Almost half of the respondents use car as their mode of transportation, followed by motorcycle and train $(16.3 \%$ and $11.3 \%$ respectively). With regards to train commuting frequency, $24 \%$ of the respondents using train at least 1-3 times per week whilst $62 \%$ travel less than 5 times per month. Nearly all of the respondents did not engage with smoking. Respondents' history diseases related to air quality were recorded which include asthma, hayfever, eczema, respiratory problems and family history of allergies. $40 \%$ of them reported having family history of allergies, followed by $15 \%$ of asthma and $14 \%$ hayfever. Least of them reported of having respiratory diseases (Table 3 ).

In order to assess respondents' knowledge on IAQ, set of questions that include 'ever heard on indoor air quality', source of indoor air pollutants, information acquaintance on IAQ and perception on health effect of IAQ were asked. More than half respondents ever heard on IAQ with $66 \%$ of them know the sources of indoor air pollutants. Furthermore, more than $20 \%$ of the respondents listed few sources of indoor air pollutants that came from incomplete combustion of coal and wood, occurrence of dust and ash, paint and adhesives as well as air conditioning. $44 \%$ of respondents obtained information on IAQ from written media (newspaper, articles, journals) while others obtained the information from other sources such as health workers, television and radio. With regards to respondents' perception on IAQ, most of them perceived that indoor air pollution and factors such as air temperature, humidity and air movement have an effect on respiratory diseases (Table 4). The result indicates a need to promote awareness on among public since the behavior of passengers influence the IAQ in train compartment [4].

Respondents were also rated the in-train environment and most of them identified unpleasant odor and stuffy 'bad' air affect their comfort during commuting (41\% and $39.5 \%$ respectively) (Refer Fig. 6). The assessment was detailed out by evaluating whether any symptoms were reported for the past three month during commuting. Most of the respondents reported they sometimes feel fatigue, headache, dizziness and irritated nose but most the time they often feel fatigue and headache when travelling with train (Fig. 7). In addition, almost half of them 
believe that such symptoms were due to in-train air environment (Fig. 8). A slight increase of $\mathrm{CO}_{2}$ concentration found in this study may be associated with the symptoms reported and such has been demonstrated in previous studies among train commuters [15-16]. The symptoms were frequently reported when number of passengers increase as $\mathrm{CO}_{2}$ was frequently released through respiration $[3,13]$.

Table 3. Respondents' socio demographic and disease history $(\mathrm{N}=129)$

\begin{tabular}{|c|c|}
\hline Demographic Factor & Frequency $(\%)$ \\
\hline \multicolumn{2}{|c|}{ Respondent's Gender } \\
\hline Male & $35(27.1)$ \\
\hline Female & $94(72.9)$ \\
\hline \multicolumn{2}{|c|}{ Respondent's Age } \\
\hline Teen & $3(2.3)$ \\
\hline 20’s & $118(91.5)$ \\
\hline 30 's & $5(3.9)$ \\
\hline 40 's & $3(2.3)$ \\
\hline \multicolumn{2}{|c|}{ Education Background } \\
\hline None & $0(0)$ \\
\hline Primary & $0(0)$ \\
\hline Secondary & $1(0.8)$ \\
\hline College & $13(10.1)$ \\
\hline University & $115(89.1)$ \\
\hline \multicolumn{2}{|c|}{ Most common modes of transportation used to work } \\
\hline Train & $15(11.6)$ \\
\hline Buses & $3(2.3)$ \\
\hline Motorcycle & $21(16.3)$ \\
\hline Car & $62(48.1)$ \\
\hline Walk & $24(18.6)$ \\
\hline Others & $4(3.1)$ \\
\hline \multicolumn{2}{|c|}{ Period of commuting by train } \\
\hline
\end{tabular}


1-3 times per week

4-7 times per week

$<5$ times per month

$>5$ times per month

Smoking habit
$31(24.03)$

7 (5.43)

$80(62.01)$

$11(8.53)$

$14(10.9)$

$115(89.1)$

g) Disease history related to air

Asthma

20(15.5)

Hayfever

18(14)

Eczema

14(10.85)

Respiratory problems

$3(2.33)$

Family history of allergies

Table 4. Respondents' knowledge on indoor air quality (IAQ) $(\mathrm{N}=129)$

\begin{tabular}{cc}
\hline Facts on Indoor Air Quality (IAQ) & Frequency (\%) \\
\hline Hes & $81(63)$ \\
No & $25(19)$ \\
Not sure & $23(18)$ \\
Do you know the sources of indoor air pollutants? \\
Yes & $85(66)$ \\
No & $19(15)$ \\
Not sure & $25(19)$ \\
What are the sources of indoor air pollutants?** & $41(14)$ \\
Incomplete combustion of coal and wood & $65(22)$ \\
Occurrence ash and dust & $53(18)$ \\
New carpet & $67(23)$ \\
Paint, glue, adhesive & $67(23)$ \\
Aircond &
\end{tabular}


How do you get the information on indoor air quality?**

From health workers

TV and radio

Newspapers, publications and journals

Others
$37(23)$

$27(17)$

$69(44)$

$26(16)$

In your opinion, does indoor air pollution have an effect on respiratory diseases?

Yes

$123(95.3)$

No

$0(0)$

Not sure

$6(4.7)$

In your opinion, does indoor air temperature, humidity and air movement have an effect on respiratory diseases?

Yes

No

Not sure
$114(88.4)$

$13(1.8)$

**Answer can be more than one

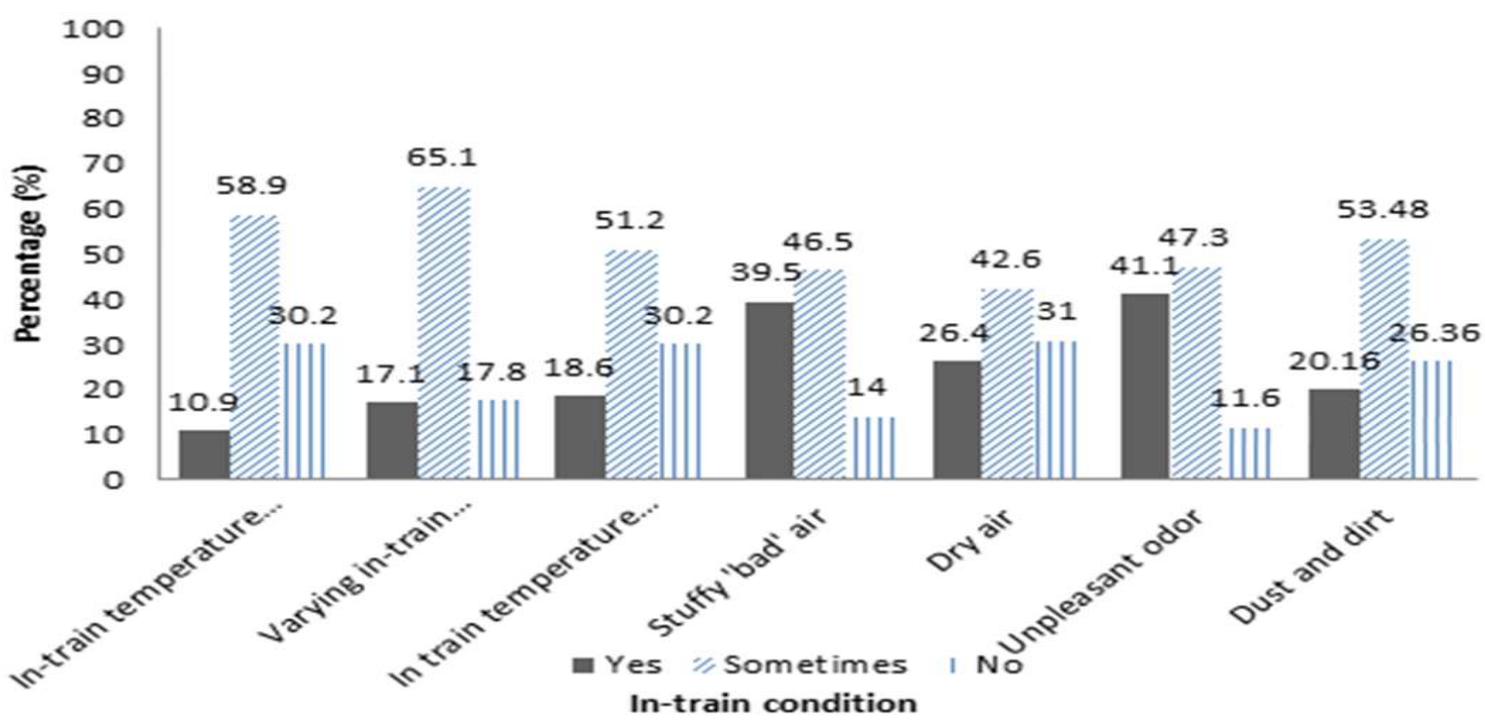

Fig.6.Respondent rate on in-train environment 


\section{Symptoms for past three months during commuting}

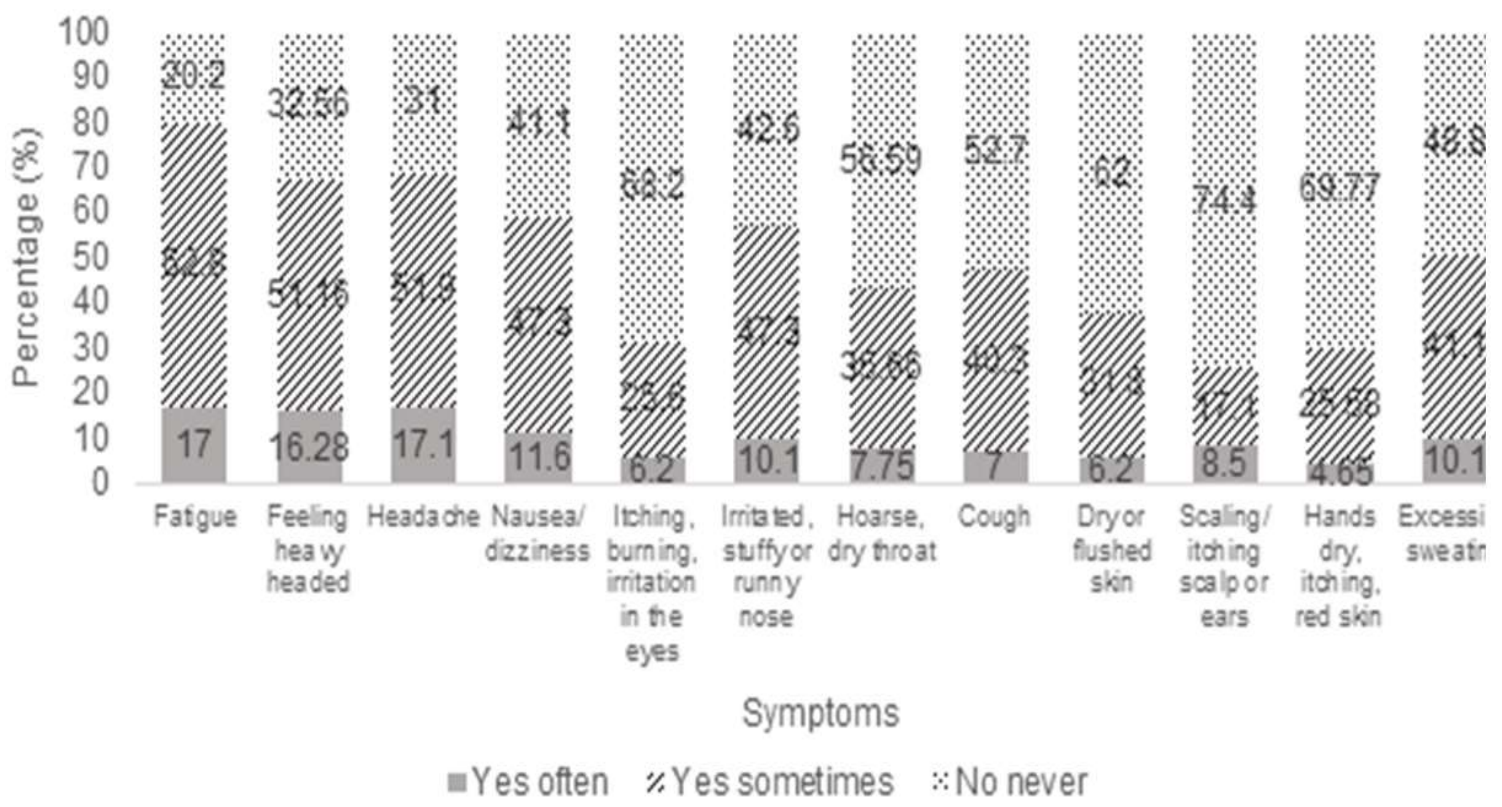

Fig.7. Symptoms reported for the past three months during commuting

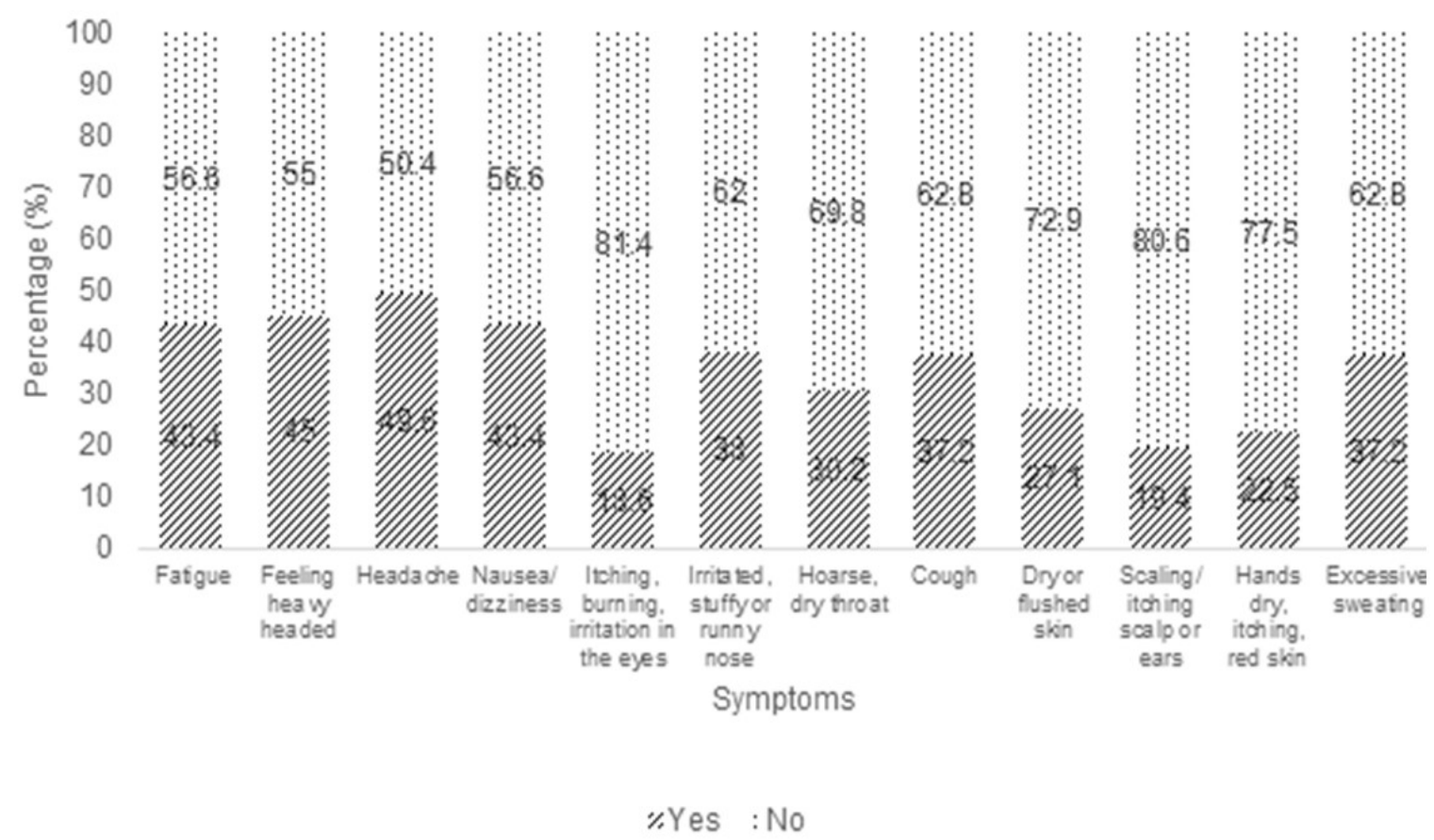

Fig.8. Respondents' perception on symptoms reported due to in-train condition

\section{CONCLUSION}

This study indicates some of the in-train air quality parameters that should be emphasized due its exceeding permissible limit. Carbon dioxide $\left(\mathrm{CO}_{2}\right)$ and $\mathrm{PM}_{10}$ concentration was most of the 
time exceed acceptable limit. This issue may affect the passengers' health in the long run. On the other hand, majority of the respondents were aware on the indoor air quality and most of them perceived that the in-train environment was poor. The study suggests that a comprehensive measures such as the installation of mechanical pressurization equipment and scheduled maintenance in order to improve in-train condition. Apart from that, an awareness program on indoor air quality (IAQ) is proposed as part of an educational program to increase public awareness on IAQ.

Despite of the finding, it is important to consider the limitation of the study. The nature of cross sectional in current study may limit the causal inferences. Therefore, it is proposed that a case control study to be employed in order to determine if the in-train condition is associated with symptoms reported. Furthermore, few previous studies demonstrated that train speed plays a role in the increasing of $\mathrm{CO}_{2}$ concentration. Thus, it is recommended that the association between train speed and total volatile organic compound (TVOC) towards the increasing of $\mathrm{CO}_{2}$ concentration to be warranted. In addition, the small number of sample size may not represent the true population of the KTM commuters. It is observed that most of the respondents were not cooperative to response to this study. Therefore, it is suggested that collaboration with KTM Berhad in the form of fee ticket discount to the commuters may assist in increase the study participation in the future.

\section{ACKNOWLEDGEMENTS}

The authors would like to express their gratitude to all participants for their contribution and participation throughout the research.

\section{REFERENCES}

[1] Chiu C O, Karim M R, Yusoff S. Mode choice between private and public transport in Klang Valley, Malaysia. Scientific World Journal, 2014, 2014:1-14

[2] Li T T, Bai Y H, Liu Z R, Liu J F, Zhang G S, Li J L. Air quality in passenger cars of the ground railway transit system in Beijing, China. Science of the Total Environment, 2006, 367(1):89-95

[3] Hidayatullah M. The analysis of indoor air quality inside the Kelana Jaya light rail transit 
train in Kuala Lumpur. Master thesis, Johor: Universiti Tun Hussein Onn Malaysia, 2015

[4] Bai G P, Gong G C. The study of indoor air quality in train compartment. In 3rd IEEEDigital Manufacturing and Automation, 2010, pp. 948-951

[5] Zuurbier M, Hoek G, Oldenwening M, Lenters V, Meliefste K, van den Hazel P, Brunekreef B. Commuters' exposure to particulate matter air pollution is affected by mode of transport, fuel type, and route. Environmental Health Perspectives, 2010, 118(6):783-789

[6] Syahirah B, Osman MM, Murad M, Ibrahim M. An assessment of commuters' perceptions of safety and comfort levels of 'Women-Only Coach': The case study of KTM Komuter Malaysia. Procedia Environmental Sciences, 2014, 20:197-205

[7] Khalid U A, Bachok S, Osman M M, Ibrahim M. User perceptions of rail public transport services in Kuala Lumpur, Malaysia: KTM Komuter. Procedia-Social and Behavioral Sciences, 2014, 153:566-573

[8] Aminah M S, Masirin M, Idrus M, Azis M I, Zainorabidin A. Appraisal on Malaysian rural rail transit operation and management system: Issues and solution in integration.In International Integrated Engineering Summit, 2014, pp. 1-11

[9] Department of Occupational Safetyand Health (DOSH) Malaysia. Industry code of practice (ICOP) on indoor air quality.Putrajaya: Ministry of Human Resources, 2010

[10] Department of Environment (DOE) Malaysia. Indoor air quality.Putrajaya: Ministry of Natural Resources and Environment, 2010

[11] Ott R. L., Longnecker M. T. An introduction to statistical methods and data analysis. Boston: Cengage Learning, 2016

[12] Andersson K. Epidemiological approach to indoor air problems. Indoor Air, 1998, 8(S4):32-39

[13] Mohd F O, Juliana J. Exposure to indoor air pollutants $\left(\mathrm{PM}_{10}, \mathrm{CO}_{2}\right.$ and $\left.\mathrm{CO}\right)$ and respiratory health effects among long distance express bus drivers. Health, 2014, 5(3):66-85

[14] Cheng X, Tan Z, Tay R, Yuan W. Air quality in transportation cabins-Part I: How much do we know about it? Transactions-American Society of Heating Refrigerating and Air Conditioning Engineers, 2012, 112(2):505-517

[15] Zhu Y, Eiguren-Fernandez A, Hinds W C, Miguel A H. In-cabin commuter exposure to ultrafine particles on Los Angeles freeways. Environmental Science and Technology, 2007, 
41(7):2138-2145

[16] Daisey J M, Angell W J, Apte M G. Indoor air quality, ventilation and health symptoms in schools: An analysis of existing information. Indoor Air, 2003, 13(1):53-64

How to cite this article:

Masyita M, Nornadiah R. In train air quality analysis of the public railway transit and public perception on in-train air quality in malaysia. J. Fundam. Appl. Sci., 2017, 9(4S), 812-827. 